\title{
The Influence of Housing for Laying Hens on the Economics of Egg Production
}

\author{
František Zigo ${ }^{*}$, Silvia Ondrašovičová ${ }^{2}$, Katarína Veszelits Lakticova $^{3}$, Mária Vargova ${ }^{4}$ \\ ${ }^{1}$ Department of Nutrition and Animal Husbandry, University of Veterinary Medicine and Phar macy, Košice, Slovakia \\ *Corresponding author's email: frantisek.zigo [AT] uvlf.sk \\ ${ }^{2}$ Department of Biology and Physiology, University of Veterinary Medicine and Pharmacy, Košice, Slovakia \\ Email: silvia.ondrasovicova [AT] uvlf.sk \\ ${ }^{3}$ Department of the Environment, Veterinary Legislation and Economy, University of Veteriny medicine and pharmacy, Košice, \\ Slovakia \\ Email: katarina.veszelitslakticova [AT] uvlf.sk \\ ${ }^{4}$ Department of the Environment, Veterinary Legislation and Economy, University of Veteriny medicine and pharmacy, Košice, \\ Slovakia \\ Email: maria.vargova [AT] uvlf.sk
}

\begin{abstract}
The poultry sector plays an importantrole in animalproduction in terms of maintaining a stable production of healthy foodfor the population. With regard to egg industry, sustainabilityrefers to the treatment of laying hens and especially the systems used for hen housing. The conditions of welfare and housing of laying hens in the production of table eggs are currently of interest to mostegg sellers as well as consumers as they directly affect the economy of their production and their price. At present, consumers have a choice offour types of eggs on the shelves. They can come from cage, litter, free range or organic farming. Each farm has well-defined rules that it must follow . Customers are increasingly interested in where and under what circumstances are produced the eggs which theybring home from the store. In addition to price, customers look for a story behind the package and make their decisions accordingly. Although recognizing that issues such as environmental consequences, food safety, and humane treatment of hens are also important, this article focuses on the relationships between hen housing and economy a nd market eggs production.
\end{abstract}

Keywords - Hens, Egg Production, Battery Cage Systems, Alternative Systems, Economics

\section{INTRODUCTION}

The chicken layer industry, or egg industry, is an important intensive animalproduction system. Eggs as an important component of human food contain full-value proteins with an optimal composition of amino acids, fats mostly with uns aturated acids, important macro and microelements, vitamins and enzymes necessary for fetal development, but als o as components of rational human nutrition. The nutrient composition of chicken eggs is presented in the table 1[1]. Over the past decade, the egg industry recorded an intensive growth due to the rising per capita consumption ofe ggs (a little over 200 eggs per year/person) [2].

Table 1: Nutrient composition of fresh chicken egg (per 100g)

\begin{tabular}{ccccccccc}
\hline Components & $\begin{array}{c}\text { energy } \\
(\mathbf{k c a l})\end{array}$ & $\begin{array}{c}\text { water } \\
(\mathbf{g})\end{array}$ & $\begin{array}{c}\text { protein } \\
(\mathbf{g})\end{array}$ & $\begin{array}{c}\text { fat } \\
(\mathbf{g})\end{array}$ & $\begin{array}{c}\text { cholesterol } \\
(\mathbf{m g})\end{array}$ & $\begin{array}{c}\text { carbohydrate } \\
(\mathbf{g})\end{array}$ & $\begin{array}{c}\text { calcium } \\
(\mathbf{m g})\end{array}$ \\
\hline whole egg & 149 & 75.33 & 12.49 & 10.02 & 425 & 1.22 & 49 \\
\hline yolk & 358 & 48.81 & 16.76 & 30.87 & 1.281 & 1.78 & 137 \\
\hline white & 50 & 87.81 & 10.52 & 0 & - & 1.03 & 6 \\
\hline
\end{tabular}

Source: Singh and Glenn [1].

The consumer's demand, and therefore also the goal of the poultry industry is a continuous supply of fresh eggs to the market. At present, consumers have a choice of four types of eggs, which can come from different laying hen technologies such as cage, litter, free range or organic farming. Each farm has well-defined ru les that it mu st follow. From January 2012, EU welfare standards for laying hens prohibit the use of conventional "barren" battery cages. Current alternative systems that are acceptable under the EU legislation are noncage systems an d enriched cag es. In enriched cages. This means that the hens have more space and "privacy" than in the past, becau se they have a perch and a 
nest to lay eggs (figure 1) [3,4,5].

The housing conditions and welfare of laying hens in the production of table eggs are currently of g reat in terest to most sellers and consumers, as they directly affect the quantity, quality and price of the eggs. The quality of table egg s produced by laying hens in the technological systems used depends on a number of internal and external factors, such as animal health and condition, nutrition, appropriate microclimatic and technological conditions of the breeding environment and other [6,7].

The specific objectives of this review are to discuss the economy of egg production using enriched cages and noncage systems, determine and compare the economic performance of each management systemas well as determine the factors which affects the final price of eggs.

\section{LAYING HENS HOUSING SYSTEMS}

High yield of laying hens is conditional upon selection of a suitable laying hybrid, proper rearing of pullets and suitable rearing technology that enables to make maximum use of their production potential, i.e. to obtain fromeach hen $300-350$ eggs of $60 \mathrm{~g}$ weight per year (16 to $21 \mathrm{~kg}$ of egg mass) [8,9]. Throughout the world, poultry industry uses mostly large-scale production technologies selected according to the climatic, nutritional, socio-economic and eth icalhuman conditions of the respective countries. Most hens are kept in halls or sheds, about $76 \%$ of themin cage bat te ries, $13 \%$ in halls on deep bedding or slatted floors and $11 \%$ in free-range or aviaries. In Argentina, Brazil, Mexico, Iran and Thailand, more than $95 \%$ of all hens intended for egg production are kept in cages. The deep litter systemis most used in Sweden, over $30 \%$ of hens are kept on litter in Aus tria and Switzerland. Free-range and aviary farms are wide s pre ad in Switzerland for up to $60 \%$ of hens and are used for about $30 \%$ of laying hens in Austria and Ireland [10,11].

Along the way, some systems were found to be unworkable and their development was discontinued, whereas others were found to be sufficiently promising for further investment and refinement. Current alternative systems that are acceptable under the EU legis lation are noncage systems and enriched cages (Figure 1).

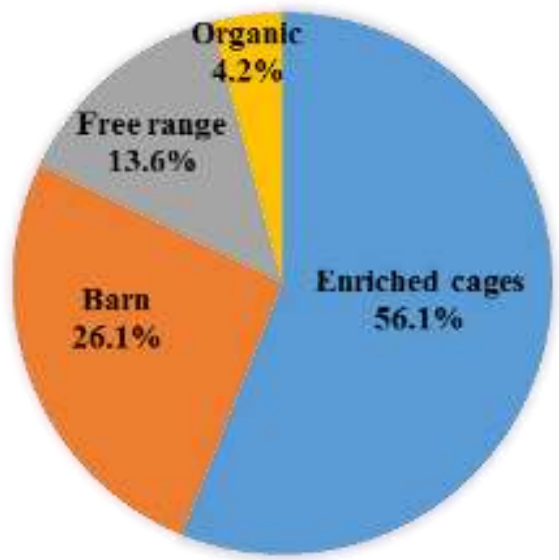

Graph 1: Housing systemin EU laying hen husbandry in 2015.

Source: Windhorst [12].

\subsection{Enriched Cages}

The construction of enriched cages is made of galvanized sheet metal, profiles and wires. The nests are separated by hinges with an area per laying hen in the range from 125 to $150 \mathrm{~cm}^{2}$. A suitable nest lining (artificial grass, etc.) significantly reduces the laying outside thenest [13]. Enriched cages have s pace for scratching, pecking and dust bathing. The side walls of the cage are made of galvanized metal sheet, the sloping bottom of the cage is plastic in order to prevent damage to the laid eggs while rolling to the automatic collection belt which transports them to the central conveyor. Manure is removed by a belt undereach deck of cages. Feed is provided by an automatic systemand consis ts of a feed trough, an automatic feed trolley, a feed conveyor and a storage silo. The supply systemconsists of water in let regulators, PVC pipes, pin feeders with a stainless steel nipples placed in the cages. The lighting is central for the en tire production section of the hall. Ventilation of the hall is ensured by electric fans with controlled dampers, fan openings are equipped with light screens and the entire systemis controlled by an automatic control unit, with an audible signal in case of failure $[14,15]$.

While the quality nutrition is important for health and productivity of all hens, enriched cages provide more space for movement and perches which reduce the incidence osteoporosis and hyperkeratosis. Hens reared in this way should have cauterized ("shortened") beaks. The appearance of blood, es pecially in laying hen s that were not subjected to beak 
treatment, signals the outbreak of cannibalis m[16].

Klecker et al. [17] and Saki et al. [18] stated that the development of cage technologies of hens was aimed at achieving optimumeconomic results, but also at improving living conditions for laying hens (e.g. improving feeding and watering systems and environmental conditions, and reducing emis sions - pre-drying of manure on manure belts). In such cage systems, the laying achieved with the most powerfulhybrid combinations of hens exceeded 300 eggs annually at a mortality rate not exceeding $0.5 \%$ per month and with a maximum of $6 \%$ of non-standard eggs, including contamin a ted eggs. A certain part of the professional, but es pecially the lay public is against this systembecause the demands of laying hens for the development of their innate manifestations and living needs are not fully satis fied in such cage technologies.
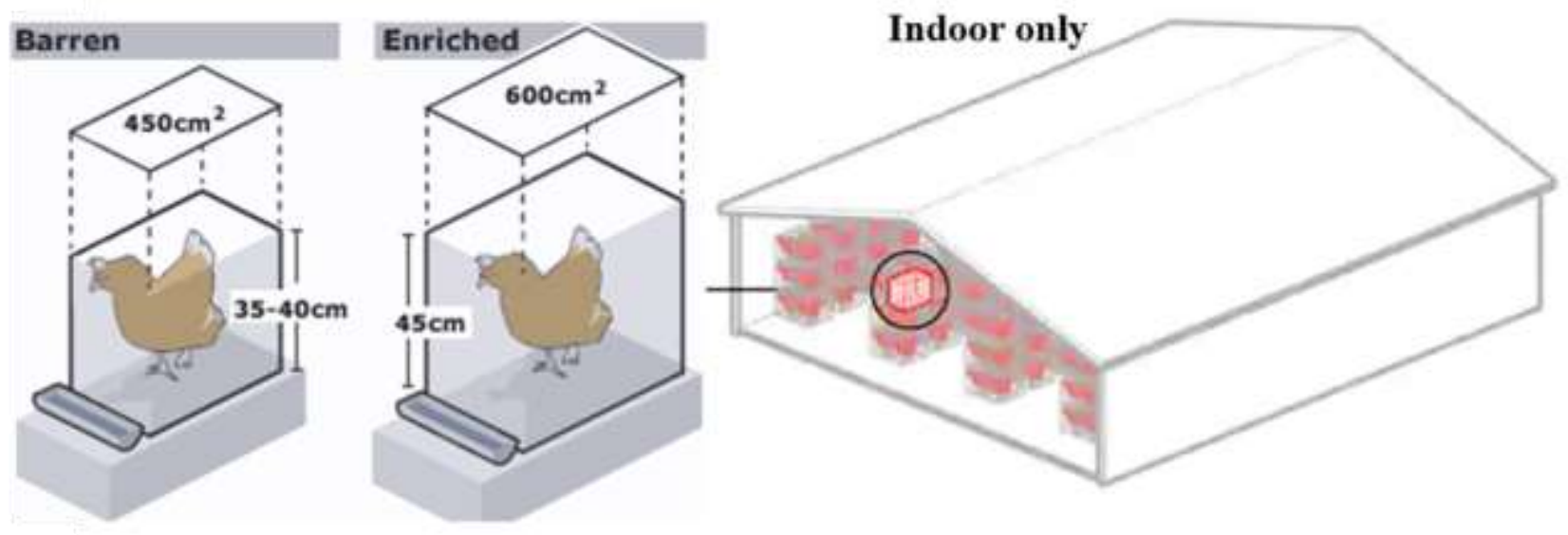

Figure 1: Comparis on of living space between barren battery cage and enriched cage system Source: Modified figure by Brulliard [19] and Windhorst [20].

\subsection{Barn Laid System}

Keeping laying hens on deep bedding is carried out in breeding halls on $10-15 \mathrm{~cm}$ litter layer. The quality of bedding significantly affects the breeding en vironment and animal welfare. The litter must not be cold and wet as this can cause sticking of litter to hens' feet and formation of "mud slippers" and an increased incidence of parasitic and bacterial diseases. At least $1 / 3$ of the floor area mus t be covered with litter. Maximum density of stocking is 9 hen s per $1 \mathrm{~m}^{2}($ at least $1110 \mathrm{~cm}^{2}$ perhen). There must be at least $15 \mathrm{~cm}$ of perch spaceper hen and access to a dust bath (Figure 2) [21].
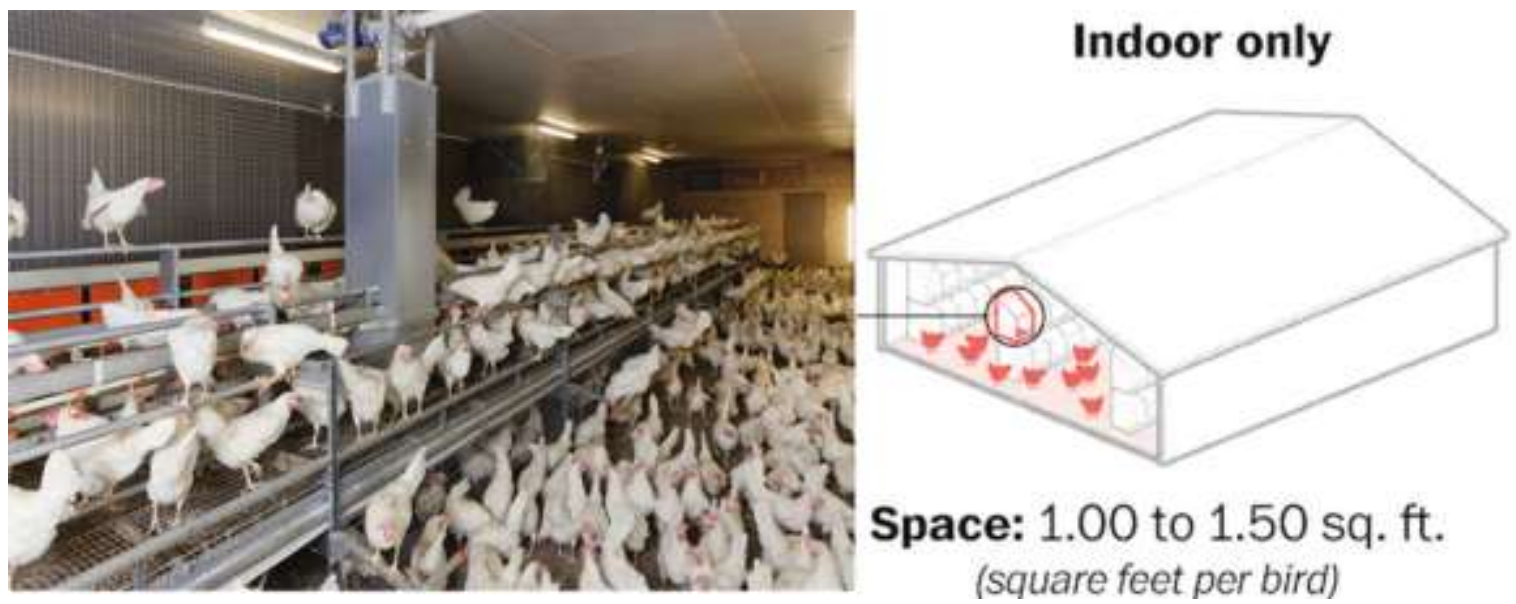

Figure 2: Barn System with litter and slatted floor, au tomated feed chain, nipple drinkers and manurebelt underneath the slatted floor

Source: Modified figure by Brulliard [19] and Windhorst [20].

An important part of the housing is the availability of nest boxes. In the modern system for housing of laying hens on deep bedding, the nests are located in the middle of the hall. This is an important as pect affecting the ins tallation of line s for feeding and watering, as well as the perches for rest. In the middle of the hall, 2 parallel rows of nests made of galvanized sheet metal (deposited on a profile structure) are placed back to back. The nesthas a removable floo r made of galvanized net, on which artificial grass is placed. The laid eggs roll to an egg collection belt. The nests are equipped 
with an automatic ejection system(reduces the retention of the hen in the nest) and ventilation (a slit in the roof of the nest). A removable slatted floor (usually below it is a belt for removal of faeces) connects to the nests. Nipple drinkers with drip cups are most often used. The feeding line is usually arranged as feeding trough with a chain conveyor. Feeders and drinkers are located above the slatted floor (therefore mostdung is trapped in the space under the slats) [22,23].

\subsection{Outdoor systems}

Outdoor systems can either be conventional free-range (or free run) systems or org anic systems. They only differ in the stocking density within the hen house. While conventional systems in the EU allow a stocking density of 9 birds per 1 $\mathrm{m}^{2}$, organic systems only permit 6 hens per $1 \mathrm{~m}^{2}$. The available outdoor s pace in both systems is $4 \mathrm{~m}^{2}$ per laying hen or a maximum of 2,500 birds perhectare. The outdoor range can be available for the hens either directly through openings in the walls or via the covered winter garden [23]. The outside area is mostly covered with grass and should offer trees, bushes or shelters to protect the hens against predators, rain, bright sunshine or cold (Figure 3) [19,20].

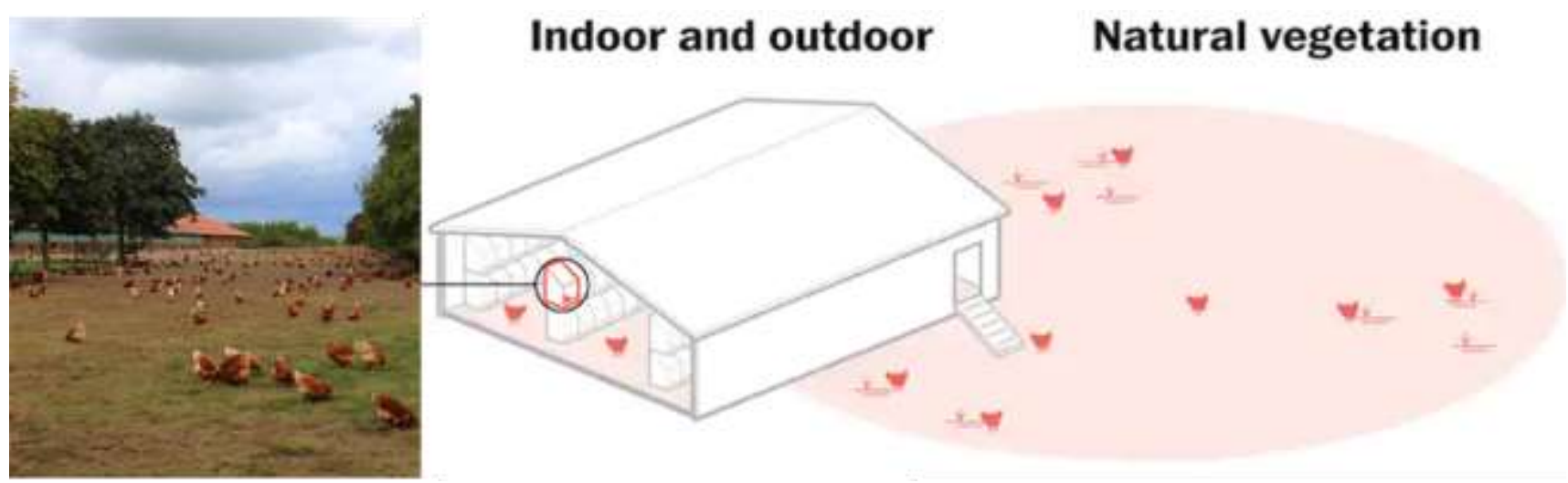

Figure 3: Free range system with range and protecting bushes Source: Modified figure by Brulliard [19] and Windhorst [20].

\subsection{Advantages and dis vantages of the housing systems}

Regardles s of the farming method, laying hens are susceptible to infectious or productive dis eases, but also to varying degrees of damage to the body, from moulting to pecking, wounds and cannibalis $m$. There are a number of un derly in $g$ genetic and production management causes, including crowding, barren environments, and lack of loose litter. Some hen strains are more likely to develop the behavior than others, particularly the medium-heavy brown hybrid birds [24].

A comprehensive analysis of the welfare of hens kept in various housing systems was undertaken by the Lay Wel research project, funded by the European Commission and several member countries of the European Union. A collaborative effort among working groups in seven different European countries that examined datacollected from 230 different laying hen flocks, the LayWel projectevaluated 16 independent experiments to study stress physiology. The researchers found that meas ures were highly inconsistent; depending on the physiological parameter measured, welfare as sessment ran the full spectrum fromappearing to improve, compare to, or decrease in cag e s relative to altern ative systems. Given their results, the LayWel project teamemphasized that physiological measurements of s tre ss must be interpreted with caution [25,26].

In the system of rearing in enriched cages we often observe feather pecking and canibalis $m$ in flocks of hen s the beaks of which were not trimmed. Manifes tations of some high-priority needs, such as a dustbathing or forag ing, are limited or even impossible to fulfil in the cage systems (Table 2) [27]. In the alternative systems the conditions for expressing normal behaviour are better, however, also in these systems some negative phen omena are observed, for example feather pecking is more dificult to control and there is higher risk of parasitoses orinfectious diseases in free ranges. In litter systems combined with a slatted floor, there are large sections where "stress intervention s" (fly in g-in birds, rodents, ubrupt turning off light, human entry, noise) cause panic and hens cluster together and may even suffocate (Table 2). Also from an ecological point of view, manipulation with manure and bedding presents proble ms. The need for straw of $1 \mathrm{~kg}$ per $\mathrm{m}^{2}$ per day at faeces production of $120 \mathrm{~kg}$ per 1,000 laying hens perday become s an is sue as not only so much litter material must be secured and safely stored but all manure after emptying the hall must be adequately treated and safely dis posed of [18]. 


\section{ECONOMIC EFFICIENCY OF EGG PRODUCTION}

The prerequisite for the economic efficiency of the production of table eggs is the use of effective biological material, optimal breeding environment, full nutrition, treatment, operational management and proper organization of the production process. Use of modern computer technology, consistent registration of income and expenditure and continuous monitoring of the production cycle are recommended [29].

\section{The main costitems for the production of table eggs include:}

$>$ rearing - the cost of rearing pullets,

$>$ housing of hens - buildings, maintenance, operation of breeding halls,

$>$ equipment - cages, feeders, drinkers,

$>$ feed - used feed during the laying period,

$>$ work - workers' salaries and administration,

$>$ veterinary service - vaccination, treatment, drugs, veterinary service,

$>$ mortality - loss of laying hens by mortality,

$>$ other costs - energy, water, etc.

The main income items of farms focusedon the production of table eggs include:

$>$ sale of eggs,

$>$ sale of hens after laying,

$>$ sale of poultry manure as fertilizer [30,31].

Table 2: Synopsis of the advantages and dis vantages of the housing systems for laying hens

\begin{tabular}{|c|c|c|}
\hline Housing system & Advantages & Dis vantages \\
\hline \multirow{5}{*}{$\begin{array}{l}\text { Enriched } \\
\text { cages }\end{array}$} & Low risk of diseases and infection with parasites & $\begin{array}{l}\text { Risk of increase of feather pecking and } \\
\text { cannibalism in non beak-trimmed groups of } \\
\text { brown genotypes }\end{array}$ \\
\hline & Comparatively low mortality & $\begin{array}{l}\text { Substantial use of perches may result in keel } \\
\text { bone damage }\end{array}$ \\
\hline & Higher space, especially in colony nest systems & $\begin{array}{l}\text { Increase of dustresulting froms cratch mats and } \\
\text { litter provision }\end{array}$ \\
\hline & Better bone strenght & $\begin{array}{l}\text { Problems of depopulation in large colon y nest } \\
\text { systems with increased risk of bone fractures }\end{array}$ \\
\hline & Low risk of bumble-foot & \\
\hline \multirow{6}{*}{$\begin{array}{c}\text { Barn laid system } \\
\text { without outdoor } \\
\text { access }\end{array}$} & & $\begin{array}{l}\text { High risk of parasitic diseases and infections } \\
\text { due to contact with faeces }\end{array}$ \\
\hline & $\begin{array}{l}\text { Higher s pace availability enables hens to } \\
\text { express most species s pecific normal behavior } \\
\text { patterns }\end{array}$ & $\begin{array}{l}\text { High risk of foot pad dermatitis resulting from } \\
\text { wet litter }\end{array}$ \\
\hline & Increased bone strength & $\begin{array}{l}\text { Increased risk of bone fractures through } \\
\text { collision with perches, nests and other amenities }\end{array}$ \\
\hline & $\begin{array}{l}\text { Higher s pace availability enables submis sive } \\
\text { hens to avoid contact with ag gressive hens }\end{array}$ & $\begin{array}{l}\text { Highly variable risk of feather pecking and } \\
\text { cannibalismresulting in high mortality values }\end{array}$ \\
\hline & $\begin{array}{l}\text { Higher s pace availability enables hens to } \\
\text { express most species s pecific normal behavior } \\
\text { patterns }\end{array}$ & $\begin{array}{l}\text { Subordinate hens may have limited access to } \\
\text { feed and water because of bullying hens }\end{array}$ \\
\hline & & Increase of dust resulting fromlitter \\
\hline \multirow{4}{*}{$\begin{array}{l}\text { Barn systems } \\
\text { with outdoor } \\
\text { access (free } \\
\text { range systems) }\end{array}$} & $\begin{array}{l}\text { Same advantages as in barn systems without } \\
\text { outdooraccess }\end{array}$ & Same as in barn systems without outdoor access \\
\hline & Abilityto forage and dust bathing in range & High risk of predation \\
\hline & & $\begin{array}{l}\text { Increased risk of infections with internal } \\
\text { parasites }\end{array}$ \\
\hline & & $\begin{array}{l}\text { High risk of introduction of highly infectious } \\
\text { diseases through wild birds }\end{array}$ \\
\hline
\end{tabular}

Source: Brulliard [18].

An example of costs and revenues within the production cycle perhen is given in the following Table 3 . The table shows the structure of costs and revenues per 1 laying hen under average conditions, the result of the ec on omic res ult 
being favourable, i.e. profit per one laying hen for the laying cycle of 1,395 EUR at a rate of return of $6.42 \%$. The table shows that the main items are feed (53.18\%), depreciation of fixed assets (12.6\%), pullets (11.52\%), wages and o ther costs around $8 \%$.

The main item in the cost of eggs - the feed, significantly affects production costs. In regions where there is a large and cheap production of feed crops (maize, wheat, soybeans) or access to sea (fish) providing animal protein, these feed mixtures account for up to 70-80\% of production costs, thus significantly affecting the economy of eg g production (China, India, USA, Argentina, Brazil). The largest producers of feed grains by the sea in the warm zone therefore produce the poultry products - eggs and meat, most efficiently [32].

In addition to feed, the efficiency of egg production is significantly affected by theclimatic and local con ditions. In the warm zone regions, layers are housed mostly in roofed cage systems or in ventilated halls. In temperate zones, airconditioned halls are used that in addition to ventilation, must be heated during the cold seasons and their lighting is artificial throughout the year. In the colder zones, the most common are solid buildings with installed air conditioning and hens kept in cages or on floor [33]. Energy costs (heat, light) as well as those of building constructions are higher compared to farms located in warmareas (USA, Argentina, Brazil) and thus production costs perhen or per $1 \mathrm{~kg}$ of egg mas s are higher [34,35].

Table 3: Cost structure and revenue to 1 hen

\begin{tabular}{ccc}
\hline Item & EUR & Value \\
\cline { 2 - 3 } & 2.764 & 11.12 \\
Rearing of pullets & 11.561 & 53.18 \\
Feed & 0.068 & 0.35 \\
Medicines & 2.056 & 8.28 \\
Wages & 3.164 & 12.60 \\
Depreciation of fixed as sets & 0.576 & 2.31 \\
Energy (gas, electricity) & 0.270 & 1.09 \\
Services & 2.220 & 8.93 \\
Other costs (consumption goods, repairs) & 1.995 & 8.02 \\
Overhead & 0.270 & 1.10 \\
Death los ses & $\mathbf{2 1 . 7 3 8}$ & $\mathbf{1 0 0 \%}$ \\
Total costs & 22.710 & 98.15 \\
Sale of eggs & 0.409 & 1.77 \\
sale of hens after laying & 0.020 & 0.08 \\
sale of manure & $\mathbf{2 3 . 1 3 3}$ & $\mathbf{1 0 0 \%}$ \\
\hline
\end{tabular}

Source: Halaj and Golian [32].

The main item in the cost of eggs - the feed, significantly affects production costs. In regions where there is a large and cheap production of feed crops (maize, wheat, soybeans) or access to sea (fish) providing animal protein, these feed mixtures account for up to 70-80\% of production costs, thus significantly affecting the economy of eg g pro duction (China, India, USA, Argentina, Brazil). The largest producers of feed grains by the sea in the warm zone therefore produce the poultry products - eggs and meat, most efficiently [32,33].

In addition to feed, the efficiency of egg production is significantly affected by theclimatic and local con ditions. In the warm zone regions, layers are housed mostly in roofed cage systems or in ventilated halls. In temperate zones, airconditioned halls are used that in addition to ventilation, must be heated during the cold seasons and their lighting is artificial throughout the year. In the colder zones, the most common are solid buildings with installed air con ditio ning and hens kept in cages or on floor. Energy costs (heat, light) as well as those of building constructions are higher compared to farms located in warmareas (USA, Argentina, Brazil) and thus production costs per hen or per $1 \mathrm{~kg}$ of egg mas s are higher [34,35].

\section{PRICE AND SALE OF EGGS}

The monetization of eggs determines the extent of demand, it depends on their price, potential ec ono mic power of consumers and the popularity of egg foods. In this res pect, the supply of eggs must be continuous, uninterrupted at reas onable prices, of high quality, fresh and commensurate with the demands of consumers [36]. After the conversion of farms with conventionalcages (banned fromJanuary 2012) to those with enriched cages, there has been a notic eable discrepancy between production costs and egg prices at sale, i.e. production became more expensive and un profitable. The reduction of hens in conventional cages and compliance with welfare requirements rapidly increased the cost of production of table eggs and thus also their price, resulting in decreased consumption of eggs percapitap articularly in countries with lower purchasing power and reduced egg production in many EU countries and increa sed imports from Asia or overseas where most laying hen farmers still produced eggs in conventional (obsolete) cage systems at lowercost [12]. 
The final price of the egg fromits production to the counter is influenced by several factors. At one end is the hen farmer who grows or buys quality GMO-free feed. He can decide whether to lock themin cages or release them into free range. Of course, he has to live with his family out of something. At the opposite end is the trader who is trying to give sales women a decent wage, meets legislative obligations and increases the culture of sales in stores. Low price is one angle of vision and high price is the opposite one. Taking both aspects into account, it is impossible to clearly define that one angle of vision can permanently bring to balance the determination of the price of eggs [37].

Table 3 shows the difference between the prices of eggs sold on the farm that produces them and their prices in the market network - shops, wholesalers or retail chains. The table shows that there are significant differences in the prices of eggs sold on the farm and in the market network. The difference in the prices of eggs depends on the country. The increase by $19.2 \%$ in the Czech Republic and decrease by $4.5 \%$ in Switzerland indicates state subsidies for egg production in Switzerland while in other countries the change involves sales overhead. Significantdifferences are in the prices of eggs on the market where the costs of packaging, storage, sales overheads and the so-called trade marg in are considered. Here the market price increase compared to cost of production is higher by $26 \%$ in In dia and $198 \%$ in the USA [32].

Table 3: Egg prices compared to production costs

\begin{tabular}{lccccc}
\hline \multirow{2}{*}{ Country } & $\begin{array}{c}\text { Cost of 1 egg/ } \\
\text { US cents }\end{array}$ & \multicolumn{2}{c}{ Price of 1 egg/US cents } & \multicolumn{2}{c}{ \% price increase/100\% } \\
\cline { 3 - 6 } & 3.66 & farm & marked & farm & marked \\
\hline USA & 3.75 & 3.92 & 10.92 & 7.10 & 198.0 \\
\hline Argentina & 2.58 & 2.67 & 6.92 & 0.0 & 84.5 \\
\hline India & 6.42 & 6.67 & 9.21 & 3.50 & 26.0 \\
\hline Hungary & 6.50 & 7.75 & 1.33 & 3.8 & 40.2 \\
\hline Czech Republic & 8.75 & 10.42 & 11.58 & 19.2 & 58.9 \\
\hline Japan & 19.17 & 18.33 & 49.50 & -4.5 & 32.4 \\
\hline Switzerland & \multicolumn{5}{c}{ Source: Halaj and Golian $[32]}$. \\
\hline
\end{tabular}

The pricing policy for poultry products deserves s pecial attention, as the retailchains sometimes increase their trade margins unjustifiably, which increases the price of eggs, lowers their consumption andis paid for by the middle and lower strata of society [38]. One way to reduce the price of eggs is to make themavailable to the consumer as soon as pos sible through market places, either directly on the farm(sale from the yard) or through buyers orlarge store houses and moved to various trade org anizations for sale or processing or long -term storage. The farmer may sell part or all of his production directly on the farm, or he may prefer different trade organizations that have their own trade chains [37].

\section{CONCLUSION}

Despite the inappropriate time pressure of retail chains to stop the sale of eggs frompoultry farms by 2025 , eg $g$ producing farmers gradually try to reconstruct their farms for the use of free-range systems of rearing that are much safer than conventional litter systems in terms of egg quality and animal welfare. However, cus tomers need to understand the fact that "mass" egg production is not compatible with alternative farming methods and the improvement of the welfare of laying hens. If the farmer satisfies the hen's daily needs and the hen has access to grassy run for forag ing and to limestone for good quality of egg shells, its eggs cannotbe sold for the price eggs produced in a cages, which are the cheapest.

\section{CONFLICTS OF INTERESTS}

Authors declare that there are no conflicts of interest.

\section{ACKNOWLEDGEMENT}

This work was supported by the Slovak project KEGA no. 006UVLF-4-2020 'Implementation of new scientific knowledge in teaching and improving the practical training of students in breeding technology from subject A nimal husbandry'.

\section{REFERENCES}

[1] Singh R.P., Froning G.W. 2020. "Egg", Encyclopædia Britannica, Available at: https://www.britannica.com/topic/egg-food

[2] Carey J.B., Kuo F.L., Anders on K.E. 1995. "Effects of cage population on the productive performance of lay ers", Poult. Sci., vol. 74, pp.633-63. 
[3] Beaumont C., Lebihan D.E., Mignon G.S., Leterrirer C. 2010. "The European experience in poultry welfare - A decade ahead", Poultry Science., vol. 89, pp. 825-83.

[4] Keeling L.J. 2004. "Nesting, perching and dust bathing", In:Perry GC. Welfare of the Laying Hen. W alling ford: CAB International, pp. 203-21.

[5] Yenice G., Kaynar O., Ileriturk M., Hira F., Hayirli A. 2016. "Quality of eggs in different production systems", Czech J. Food Sci., vol. 34, pp. 370-376.

[6] Rodenburg T.B., Tuyttens F.A.M., Sonck B., De Koen R., Lieve H., Johan. Z. 2005. "Welfare, health, and hygiene of laying hens housed in furnished cages and in alternative housing systems", J. Appl. Anim. Welf. Sci., v ol. 8, pp . 211-226.

[7] Suto Z., Horn P., Ujvari J. 1997. "The effect of different housing systems on production and egg quality traits of brown and Leghorn type layers", Acta Agrar. Kaposvariensis., vol. 1, pp. 29-35.

[8] Roland D.A., Bryant M.M., Zhang J.X., Roland D.S. Jr., Rao S.K., Self J. 1998. "Econometric feeding and management. Maximizing profits in Hy-Line W36 hens by optimizing total sulfur amino acid intake and environmentaltemperature “, J. Appl. Poult. Res., vol.7, pp. 403-411.

[9] Tauson R., Wahlstrom A., Abrahamsson P. 1999. "Effect of two floor housing systems and cages on health, production, and fear response in layers “, Journal of Applied Poultry Res earch., vol.8 (no.2), pp. 152-9.

[10] Anderson K.E., Adams A.W. 1992. "Effects of rearing space and feeder and waterer spaces on the productivity and fearfulbehavior of layers “, Poult. Sci., vol. 71, pp. 53-58.

[11] Arpášová H., Kokos zyński D., Haščík P., HrnčárC., Hamadová1 M., Fik1 M., Murdzik S. 2020. "Influence of the Housing Systemon Physical Quality Indicatorsof the Internal Content of Laying Hens Table eggs“, Animal Science and Biotechnologies, vol. 53(no.2), pp. 221-228.

[12] Windhorst H.W. 2017. "The EU egg industry", Zootecnica International, Available at: https://zootecnicainternational.com/focus-on/eu-egg-industry/

[13] Lee H.W., Louton H., Schwarzer A., Rauch E., Probst A., Shao S., et al. 2016. "Effects of multiple daily litter applications on the dust bathing behaviour of laying hens kept in an enriched cage system", Applied Animal Behaviour Science., vol. 178, pp.51-59.

[14] Briese A., Sewerin K., Knierim U., Hartung J. 2001. "Enriched cage systems for laying hens: Minimum stan dards and as pects of their scientific evaluation", In: Deutsche Tieraerzliche Wochenschrift, vol. 108, pp. 105-09. ISSN: 0341-6593.

[15] Sarica M., Boga S., Yamak U.S. 2008. "The effects of space allowance on egg yield, egg quality and plumage condition of laying hens in battery cages", Czech J. Anim. Sci., vol. 53, pp. 346-353.

[16] Onbas 1lar T.E. E., Aks oy F.T. 2005. "Stress parameters and immune response of layers under different ca ge flo or and density conditions", Livest. Prod. Sci., vol. 95, pp. 255-263.

[17] Klecker D. 2004. "Hodnocení nových technologických systémůpro chov slepic v užitkových chovech (Evaluation of new technological systems for the breeding of hens in commercial farms )“" Náš chov, vol. 3, pp. 20-22.

[18] Saki A.A., Zamani P., Mohammadimehr M., Mahmoudi H.. (2012). "The effect of cage density on laying hen performance, egg quality, and excreta minerals “, The Journal of Applied Poultry Res earch., vol. 21, pp. 467-475. 10.3382/japr.2010-00318.

[19] Brulliard K. 2017. "Many people think a cage-free life is better for hens - It's not that simple", W ashingt on Post, Available at:https:/www.washingtonpost.com/news/animalia/wp/2017/06/15/many-people-think-cage-free-life-is better-for-hens-its-not-that-simple/

[20] W indhorst H.W. 2017. "Hous ing systems in laying hen husbandry- First part", Zootecnica International, A vailable at: https://zootecnicainternational.com/featured/housing-systems-laying-hen-husbandry/

[21] Appleby M.C., Hughes B.O. 1991. "Welfare of laying hens in cages and alternative systems: environmental, physical and behavioural aspects“", W orld's Poultry Science Journal., vol. 47(no.2), pp. 109-28.

[22] Fanatico A. 2006. "Alternative poultry production systems and outdoor access ", National Sustainable A gricultu re Information Service. Available at:www.attra.ncat.org/attra-pub/PDF/poultryoverview.pdf.

[23] Angelovičová M., Mellen M., Zdechovanová J. 2013. "Applying the principles of welfare and a quality of production in the organic farmof the laying hens", Potravinarstvo., vol. 7( no.1), pp. 120-129.

[24] Newberry R.C. 2004. "Cannibalism. In: Perry GC (ed.), Welfare of the Laying Hen“, Poultry Science Symposium Series 27 (Walling ford, U.K.: CABI Publishing).

[25] EFSA. 2005. "European Food Safety Authority, Animal Health and Animal Welfare“, Scientific report on the welfare as pects of various systems for keeping laying hens. EFSA-Q-2003-92, Annex to The EFSA Journal., pp. 78.

[26] Blokuis H.J., Van Niekerk F.T., Bessei W., Els on A., Guèmenè D., Kjaer J.B., Levrino M.G.A., Nicol C.J., Tau s on R., Weeks C.A., Van der Weerd H.A. 2007. "The Lay Wel project: Welfare implications of changes in prod uction sys tems for laying hens", World's Poultry Science., vol. 63, pp. 101-114.

[27] Shields S.J., Duncan I.J.H. 2004. “An HSUS Report: A comparison of the welfare of hens in battery cages and alternative systems ", Washington: The Humane Society of the United States. 
[28] Tablant N.L., Vaillancourt J.P., Martin S.W., Shoukri M., Estevez I. 2000. "Spatial distribution of cannibalism mortalities in commercial laying hens", Poultry Science., vol. 79, pp. 705-708.

[29] Hughes B.O., Gilbert A.B., Brown M.F. 1986. "Categorization and causes of abnormal egg s hells: Relationship with stres s", British Poultry Science., vol.27, pp.325-337.

[30] Halaj M., Arpášová H., Roháčik,B., Halaj P.2002. "Úžitkovost' a kvalita vajec sliepokv opakovaných zná ško vých cykloch (Performance and egg quality of laying hens in repeated laying cycles)“', 1st ed.Nitra: Garmond., pp. 89. ISBN-80: 96865978.

[31] Hrnčár C. 2006. "Reprodukcia hydiny-výživa (Reproductionof poultry-Nutrition)“', Chovatel',, vol. 42(no.12), pp. 4.

[32] Halaj M., Golian J. 2011. "Table eggs characteristics", Nitra: Garmond., pp.37-62. (in Slovak).

[33] Arpášová H., Kačániová M., Haščík P., Šidlová V. 2012. "Effect of selected feed additives on internal qualityparameters of table eggs", Potravinarstvo., vol. 6(no.4), pp. 52-61.

[34] Ayinde I.A., Ibrahim S.B., Arowolo, S. O. 2012. "Economics of poultry egg production under two management systems in Ogun state, Nigeria“", Nigerian Journal of Agricultural Economics (NJAE)., vol. 3 (no.1), pp. 40-49.

[35] Xin H., Gates R.S., Green A.R., Mitloehner F.M., Moore P.A J.r, Wathes C.M. 2011. "Environmental impacts and sus tainability of egg production systems“, Poult Sci. Ja., vol. 90 (no.1), pp. 263-77.

[36] RoubalováM. 2011. "Vývoj na trhu vajec v roce 2010 (Development of the eggs market in 2010)“, Náš chov., vol. 71 (no. 7), pp. 62.

[37] Halaj M. 2018. "Efektívnost' výroby a predaja slepačích vajec (Efficiency of production and s ale of hen eggs)", Rol’nícke Noviny, vol. 30. Available at:https://www.rno.sk/efektivnost-vyroby-a-predaja-slepacich-vajec/

[38] Sumner D.A., Gow H., Hayes D., Matthews W., Norwood B., Rosen-Molina J.T., Thurman W. 2011. "Economic and market is sues on the sustainability of egg production in the United States: analysis of altern ative production systems“, Poult Sci. vol. 90 (no.1), pp. 241-50. 